\title{
HUBUNGAN KEPATUHAN PERAWAT DALAM PENERAPAN STANDAR OPERASIONAL PROSEDUR (SOP) TEKNIK MENYUNTIK DENGAN PENCEGAHAN KEJADIAN TERTUSUK JARUM DI RUMAH SAKIT
}

\author{
Ahsan', Niko Dima², Kadek Chintya Nurlita Widyahastuti ${ }^{3}$ \\ Program Studi IImu Keperawatan Fakultas Kedokteran Universitas Brawijaya \\ E-mail : ahsanfkub@yahoo.com
}

\begin{abstract}
Nurses in hospitals are at risk of disease and occupational accidents in accordance with the actions taken. The most common occupational accident is used needle stick puncture wound while taking an injection, more commonly known as the Needle Stick Injury (NSI). If nurses do not comply with the application of SOP of injecting techniques, this can cause needle-punctured occupational accidents that have an impact on the transmission of pathogenic infections that endanger the nurses and patients themselves. Therefore, the role of SOP programs is very important to avoid occupational accidents, specifically the incidence of Needle Stick Injury. The aim of this study is to identify the relationship between nurse compliance on the application of injecting technique standard operating procedure with the prevention of needle stick injury in the hospital. The method of this study is Descriptive correlational study with cross sectional design approach by using observations to adhere to the application of injecting and prevention of needle stick injury incidence. The results of the study from 48 nurses in three class III inpatient wards at Kanjuruhan Hospital showed that almost all implementing nurses adhered to the implementation of Injecting technique SOP were as many as 46 nurses (95,8\%) and a small number of implementing nurses were less compliant as many as 2 nurses $(4,2 \%)$. Observation results of NSI incidence prevention of nurses found that almost all nurses had safelactions in theprevention of NSI incidence as many as 38 nurses $(79,2 \%)$ and a small number of nurses had unsafe actions as much as 10 nurses (20,8\%). Spearman rank test obtained by the correlation coefficien of $(0,406)$ with a significance value of $(0.004)$ lesser $\alpha(0,05)$. It can be concluded that there is a significant relationship between nurse adherence in the application of Injecting technique SOP with the prevention of needle stick injury incidence in hospital.
\end{abstract}

Keywords : Compliance of injecting techniques, needle stick injury prevention

Abstrak. Perawat di rumah sakit berisiko terkena penyakit dan kecelakaan kerja sesuai dengan tindakan yang dilakukan. Kecelakaan kerja yang paling umum terjadi adalah luka tertusuk jarum suntik bekas pasien saat melakukan tindakan injeksi, lebih sering dikenal dengan istilah Needle Stick Injury $(N S I)$. Jika perawat tidak patuh dalam penerapan SOP teknik menyuntik dapat menyebabkan kecelakaan kerja tertusuk jarum berdampak pada penularan infeksi patogen yang membahayakan diri perawat dan pasien. Sehingga peranan program SOP sangat penting untuk terhindar dari kecelakaan kerja yaitu kejadian tertusuk jarum suntik atau NSI. Tujuan dari penelitian ini adalah mengidentifikasi hubungan kepatuhan perawat dalam penerapan SOP menyuntik dengan pencegahan kejadian tertusuk jarum di rumah sakit. Metode yang digunakan adalah deskriptif korelatif dengan pendekatan cross sectional design menggunakan observasi untuk kepatuhan penerapan SOP tindakan menyuntik dan pencegahan kejadian tertusuk jarum. Hasil penelitian didapatkan = dari 48 perawat di 3 ruang rawat inap kelas III RSUD Kanjuruhan Kepanjen hampir semua perawat pelaksana patuh dalam penerapan SOP teknik menyuntik sebanyak 46 perawat $(95,8 \%)$ dan sebagian kecil kurang patuh sebanyak 2 perawat $(4,2 \%)$. Hasil observasi pencegahan kejadian tertusuk jarum didapatkan bahwa hampir semua memiliki tindakan aman dalam pencegahan kejadian tertusuk jarum sebanyak 38 perawat $(79,2 \%)$ dan sebagian kecil memiliki tindakan tidak aman sebanyak 10 perawat $(20,8 \%)$. Hasil uji rank spearman didapatkan koefisien korelasi sebesar $(0,406)$ dengan nilai signifikansi sebesar $(0,004)$ lebih kecil a $(0,05)$. Dapat disimpulkan bahwa terdapat hubungan yang signifikan antara kepatuhan perawat dalam penerapan SOP teknik menyuntik dengan pencegahan kejadian tertusuk jarum di rumah sakit

Kata Kunci : Kepatuhan teknik menyuntik, pencegahan tertusuk jarum 


\section{PENDAHULUAN}

Rumah sakit adalah sebuah industri jasa yang mempunyai beragam masalah ketenagakerjaan antara lain masalah keselamatan dan kesehatan kerja. Tenaga kerja di rumah sakit berisiko terkena penyakit akibat kerja dan kecelakaan kerja sesuai dengan jenis pekerjaannya (Wichaksana, 2002). Kecelakaan kerja adalah insiden yang menimbulkan cidera, penyakit akibat kerja ataupun kefatalan yang menyebabkan kematian (OHSAS, 2007).

Ancaman kecelakaan kerja di tempat kerja di negara berkembang seperti Indonesia masih sangat tinggi. Hasil laporan National Safety Council tahun 1988 menunjukkan bahwa terjadinya kecelakaan kerja di rumah sakit $41 \%$ lebih besar dari pekerja industri lainnya (Sholihah, 2013).

Kecelakaan kerja yang paling umum terjadi di pelayanan kesehatan adalah luka tertusuk jarum suntik bekas dipakai pada pasien yang menusuk kulit seorang petugas pelayanan kesehatan saat melakukan tindakan injeksi, lebih sering dikenal dengan istilah Needle Stick Injury atau NSI (Sahara, 2011). Tiga pajanan tertinggi yang menyebabkan kejadian luka tertusuk jarum pada perawat meliputi prosedur menyuntik $(21 \%)$, prosedur menjahit (17\%), dan prosedur pengambilan darah (16\%) (Ramsay, 2005).

Cidera akibat tusukan jarum pada perawat merupakan masalah yang signifikan dalam institusi pelayanan kesehatan. Perawat yang tanpa sengaja menusuk dirinya sendiri dengan jarum suntik yang sebelumnya masuk ke dalam jaringan tubuh pasien, perawat beresiko

\section{METODE PENELITIAN}

Desain penelitian yang digunakan dalam penelitian ini adalah deskriptif korelatif dengan menggunakan pendekatan cross sectional untuk mengetahui adanya hubungan kepatuhan perawat dalam penerapan standar operasional prosedur teknik menyuntik dengan pencegahan kejadian tertusuk jarum di rumah sakit. Populasi dalam penelitian ini adalah perawat pelaksana di ruang rawat inap RSUD Kanjuruhan Sampel dalam penelitian adalah seluruh perawat pelaksana di ruang rawat inap kelas III. Jumlah perawat pelaksana di ruang rawat inap RSUD Kanjuruhan Kepanjen sebanyak 48 perawat, terbagi ke dalam 3 ruang rawat inap. Pengambilan sampel menggunakan teknik non probability sampling dengan menggunakan pendekatan total sampling. Tahap pelaksanaan pengambilan data oleh peneliti di RSUD Kanjuruhan Kepanjen dilakukan pada tanggal 1 September terpapar sekurang-kurangnya 20 patogen potensial. Dua patogen yang paling menyebabkan masalah ialah Hepatitis B (HBV), Hepatitis C (HCV) dan Human Immunodeficiency Virus atau HIV yang merupakan penyakit menular dapat menyebabkan kematian. Ini merupakan risiko terbesar yang dihadapi petugas kesehatan pada garis terdepan (ANA, 2002).

Perilaku perawat dalam bekerja berpedoman pada Standar Operasional Prosedur (SOP) yang ditetapkan dari rumah sakit. Jika perawat tidak patuh dalam penerapan SOP teknik menyuntik dapat menyebabkan kecelakaan kerja tertusuk jarum suntik yang berdampak pada penularan infeksi patogen yang membahayakan diri perawat dan pasien sehingga peranan program SOP sangat penting untuk terhindar dari kecelakaan kerja.

Hasil studi pendahuluan yang dilakukan pada Bulan Agustus 2018 berupa wawancara secara langsung terhadap beberapa perawat pelaksana di ruang rawat inap RSUD Kanjuruhan Kepanjen dalam kurun waktu 5 tahun terakhir didapatkan hasil bahwa 7 orang perawat pernah mengalami tertusuk jarum suntik saat melakukan tindakan keperawatan di ruangan. Berdasarkan latar belakang yang telah diuraikan di atas maka peneliti tertarik ingin melakukan penelitian dengan judul "Hubungan Kepatuhan Dalam Penerapan Standar Prosedur Operasional Teknik Menyuntik Dengan Pencegahan Kejadian Tertusuk Jarum Di Rumah Sakit".

- 30 September 2018 di 3 ruang rawat inap. Pengambilan data kepatuhan dalam penerapan SOP teknik menyuntik di ruangan dan pencegahan kejadian tertusuk jarum peneliti melakukan observasi secara langsung pada perawat. Peneliti memberikan informed consent kepada responden (perawat) yang akan melakukan tindakan menyuntik yang bekerja di ruang rawat inap RSUD Kanjuruhan Kepanjen yang sebelumnya sudah berkoordinasi dengan pihak kepala ruangan. Peneliti melakukan observasi secara langsung dengan membawa lembar observasi yang akan diisi oleh peneliti tentang kepatuhan perawat dalam penerapan SOP teknik menyuntik dan pencegahanan kejadian tertusuk jarum melalui penanganan jarum suntik bekas pakai oleh perawat pelaksana, yang sebelumnya peneliti telah mengetahui SOP tindakan menyuntik yang berlaku di 
ruangan dari pihak pelayanan keperawatan rumah sakit sehingga dapat digunakan sebagai pedoman untuk melakukan observasi. Setelah observasi selesai, peneliti selanjutnya menganalisis tentang apakah ada hubungan kepatuhan perawat dalam penerapan SOP teknik menyuntik dengan pencegahan kejadian tertusuk jarum di ruang rawat inap kelas III RSUD Kanjuruhan Kepanjen.

\section{HASIL PENELITIAN}

\section{Tabel 1 Karakteristik responden}

\begin{tabular}{lcc}
\hline \multicolumn{1}{c}{ Karakteristik responden } & Frekuensi & Persentase (\%) \\
\hline $\begin{array}{l}\text { Jenis kelamin } \\
\text { Laki-laki }\end{array}$ & 28 perawat & 58,3 \\
Perempuan & 20 perawat & 41,7 \\
Usia & & \\
$21-30$ tahun & 19 perawat & 39,6 \\
$31-40$ tahun & 22 perawat & 45,8 \\
$41-50$ tahun & 5 perawat & 10,2 \\
$51-60$ tahun & 2 perawat & 4,2 \\
Pendidikan terakhir & & \\
D3 Keperawatan & 44 perawat & 91,7 \\
S1 Keperawatan & 4 perawat & 8,3 \\
Lama bekerja & & \\
$0-5$ tahun & 15 perawat & 31,3 \\
6-10 tahun & 16 perawat & 33,3 \\
$11-15$ tahun & 14 perawat & 29,2 \\
$16-20$ tahun & 1 perawat & 2,1 \\
>25 tahun & 2 perawat & 4,2 \\
Pengalaman tertusuk Jarum & & \\
Pernah & 7 perawat & 14,6 \\
Tidak Pernah & 41 perawat & 85,4 \\
\hline
\end{tabular}

Hasil penelitian tentang karakteristik jenis kelamin responden menunjukkan bahwa sebagian besar responden berjenis kelamin laki - laki yaitu sebesar 28 orang $(58,3 \%)$, berusia 31 - 40 tahun sejumlah 22 perawat $(45,8 \%)$. Usia 31 - 40 tahun merupakan usia dewasa muda dimana pada usia ini individu memiliki komitmen dan kompetensi dan sudah mampu memutuskan untuk berkarir. Pendidikan terakhir responden menunjukkan bahwa sebagian besar responden memiliki pendidikan terakhir D3 keperawatan yaitu sebanyak 44 perawat $(91,7 \%)$, lama bekerja responden sebagian besar bekerja selama 6 10 tahun sebanyak 16 orang $(33,3 \%)$. Pengalaman tertusuk jarum sesuai hasil penelitian didapatkan hampir semua responden, tidak pernah mengalami tertusuk jarum suntik sebanyak 41 orang $(85,4 \%)$.

Tabel 2 Data Kepatuhan Perawat Dalam Penerapan SOP Teknik Menyuntik

\begin{tabular}{lcc}
\hline $\begin{array}{l}\text { Kepatuhan penerapan SOP } \\
\text { Teknik Menyuntik }\end{array}$ & Frekuensi & Prosentase \\
\hline Kurang Patuh & 2 Perawat & $4,2 \%$ \\
Patuh & 46 Perawat & $\mathbf{9 5 , 8 \%}$ \\
\hline Total & 48 Perawat & $\mathbf{1 0 0 \%}$ \\
\hline
\end{tabular}

Hasil observasi tentang kepatuhan penerapan standar operasional prosedur teknik menyuntik di ruangan menunjukkan bahwa hampir semua responden berada dalam kategori patuh yaitu sebanyak 46 responden $(95,8 \%)$. 
Tabel 3. Pencegahan Kejadian Tertusuk Jarum Suntik

\begin{tabular}{lcc}
\hline $\begin{array}{l}\text { Pencegahan Kejadian } \\
\text { Tertusuk Jarum }\end{array}$ & Frekuensi & Prosentase \\
\hline Tidak Aman & 10 perawat & $20,8 \%$ \\
Aman & 38 perawat & $\mathbf{7 9 , 2 \%}$ \\
\hline Total & 48 Perawat & $\mathbf{1 0 0 \%}$ \\
\hline
\end{tabular}

Hasil observasi tentang pencegahan kejadian tertusuk jarum suntik di ruangan menunjukkan hampir semua responden memiliki tindakan aman dalam penanganan jarum suntik bekas pakai, yaitu sebanyak 38 responden $(79,2 \%)$.

\section{Tabel 4 Tabulasi Silang Kepatuhan Penerapan SOP Teknik Menyuntik dengan Pencegahan Kejadian Tertusuk Jarum}

\begin{tabular}{cccc}
\hline \multirow{2}{*}{$\begin{array}{c}\text { Kepatuhan Penerapan SOP } \\
\text { Teknik Menyuntik }\end{array}$} & \multicolumn{3}{c}{ Pencegahan Kejadian Tertusuk Jarum } \\
\cline { 2 - 4 } & Tidak Aman & Aman & Total \\
\hline Tidak Patuh & 0 & 0 & $\mathbf{0}$ \\
& $(0 \%)$ & $(0 \%)$ & $(\mathbf{0 \% )}$ \\
Kurang Patuh & 2 & 0 & $\mathbf{2}$ \\
& $(4,2 \%)$ & $(0 \%)$ & $\mathbf{( 4 , 2 \% )}$ \\
Patuh & 8 & 38 & $\mathbf{4 6}$ \\
& $(16,6 \%)$ & $(79,2 \%)$ & $\mathbf{( 9 5 , 8 \% )}$ \\
\hline Total & $\mathbf{1 0}$ & $\mathbf{3 8}$ & $\mathbf{4 8}$ \\
& $(\mathbf{2 0 , 8 \% )}$ & $(\mathbf{7 9 , 2} \%)$ & $(\mathbf{1 0 0 \% )}$ \\
\hline
\end{tabular}

Hasil penelitian menunjukkan bahwa dari 48 responden, hampir semua (79,2\%) responden yang memiliki kepatuhan dalam penerapan SOP teknik menyuntik dan memiliki tindakan aman dalam pencegahan kejadian tertusuk jarum.

Pengujian secara statistik dengan menggunakan uji Rank-Spearman untuk mengetahui adanya hubungan kepatuhan dalam penerapan SOP teknik menyuntik dengan pencegahan kejadian tertusuk jarum diperoleh nilai signifikansi 0,004 dan besar korelasi ( $r$ ) adalah 0,406 dengan kekuatan korelasi moderate atau sedang. Hasil uji

\section{PEMBAHASAN}

Kepatuhan perawat adalah perilaku perawat terhadap suatu tindakan, prosedur atau peraturan yang harus dilakukan atau ditaati (Notoatmodjo, 2007). Hasil penelitian dan analisa data yang dilakukan, didapatkan bahwa hampir semua responden memiliki kepatuhan terkait penerapan SOP teknik menyuntik. Kepatuhan ini disebabkan karena perawat di RSUD Kanjuruhan bekerja sesuai prosedur teknik menyuntik yang berlaku. Hal ini sejalan dengan penelitian yang dilakukan oleh Idayanti (2008) di RSUD Arifin Achmad Pekanbaru mengenai pengetahuan dan sikap perawat di ruangan terhadap penerapan SOP teknik menyuntik, sebagian besar responden di ruang rawat inap memiliki pengetahuan tinggi dan sikap sangat baik sehingga korelasi rank-spearman diketahui bahwa nilai signifikansi 0,004 ( $p$-value<0,05), maka hipotesis nol ditolak yang berarti terdapat hubungan kepatuhan perawat dalam penerapan standar operasional prosedur teknik menyuntik dengan pencegahan kejadian tertusuk jarum di rumah sakit.

menerapkan SOP teknik menyuntik dengan kategori baik sesuai dengan pedoman persiapan alat dan pelaksanaannya.

Kepatuhan yang dimiliki perawat dalam penerapan SOP dihubungkan dengan beberapa karakteristik. Karakteristik yang pertama adalah usia responden. Dari hasil penelitian didapatkan sebagian besar responden berusia 31 - 40 tahun. Sebagian besar responden berusia 31-40 tahun yang merupakan usia dewasa muda dimana usia dewasa muda dimulai dari usia 18 tahun dan berakhir pada usia 35 sampai 40 tahun yang ditandai dengan adanya kemandirian secara finansial dan orang tua serta adanya rasa tanggung jawab terhadap tindakan-tindakan yang dilakukan (Prasiska, 2018). 
Selain usia dapat dilihat dari jenis kelamin dimana pada penelitian ini sebagian besar responden dengan jenis kelamin laki-laki. Hal ini dikarenakan pada salah satu ruangan memiliki ruang rawat inap yang berbeda untuk pasien perempuan dan laki-laki sehingga jumlah perawat dengan jenis kelamin laki-laki lebih banyak dari perawat perempuan. Hal ini tidak sesuai dengan penelitian yang dilakukan oleh Yanti dan Warsito (2013) dimana pekerjaan perawat lebih diminati oleh perempuan.

Dalam penelitian ini karakteristik pendidikan terakhir, hampir semua responden memiliki pendidikan D3 keperawatan. Penelitian ini sejalan dengan penelitian yang dilakukan Sanjaya, Rosa dan Ulfa (2017) yang menyatakan bahwa perawat yang berada di ruang rawat inap dan IGD di RS Pupuk Kaltim mayoritas berpendidikan Diploma III Keperawatan, dengan demikian diharapkan bahwa perawat akan memberikanAasuhan keperawatan dengan baik untuk keselamatan pasien. Tingkat pendidikan merupakan salah satu faktor yang mempengaruhi tingkat pengetahuan seseorang, sehingga perawat yang memiliki tingkat pendidikan tinggi cenderung memiliki tingkat pengetahuan yang baik (Lake, Shang, Klaus \& Dunton 2010).

Dalam penelitian ini dilihat dari karakteristik masa kerja perawat, sebagian besar responden lama bekerja 6-10 tahun. Hal ini sesuai menurut Millah (2008) bahwa semakin lama masa kerja seseorang maka pengalaman yang diperoleh semakin banyak yang memungkinkan perawat dapat bekerja lebih aman karena pengalaman yang dimiliki dapat mempengaruhi perilaku dalam kehidupan pekerjaannya.

Berdasarkan karakteristik pengalaman tertusuk jarum, sebagian besar responden tidak pernah mengalami tertusuk jarum suntik saat melakukan tindakan keperawatan. Terdapat sebagian kecil responden yang pernah mengalami tertusuk jarum suntik saat melakukan tindakan keperawatan dalam kurun waktu lima tahun terakhir.

Hasil penelitian diketahui bahwa sebagian besar responden memiliki tindakan aman dalam pencegahan kejadian tertusuk jarum suntik diruang rawat inap yang bertempat di RSUD Kanjuruhan. Hal ini kemungkinan disebabkan karena pihak RS Kanjuruhan menggunakan sistim intravena tanpa jarum seperti penggunaan venvlon untuk meminimalisir penusukan menggunakan jarum di ruangan saat melakukan tindakan menyuntik guna memasukkan obat melalui infus yang terpasang pada pasien dan perawat di ruang rawat inap juga sudah menggunakan jarum suntik dengan desain keamanan sendiri. Hal ini sesuai dengan penelitian Intan (2013) yang menyatakan pemanfaatan alat suntik dengan rekayasa safety design dan penggunaan sistem intravena tanpa jarum diperlukan untuk peningkatan keamanan menyuntik guna mencegah kejadian tertusuk jarum suntik yang lebih baik.

Perawat di ruang rawat inap RSUD Kanjuruhan sebagian besar belum melakukan non-recaping atau tidak menutup kembali jarum sesudah digunakan. Hampir semua responden masih menutup jarum terlebih dahulu sebelum dimasukkan ke kontainer pembuangan benda tajam, menggunakan metode satu tangan maupun dua tangan. Hal ini sejalan dengan peneltian yang dilakukan Muslim (2013) bahwa perawat di RS Kendal yang menutup jarum suntik setelah melakukan penyuntikan lebih tinggi dari pada perawat yang langsung memasukkan jarum suntik ke kontainer pembuangan sehingga sebagian besar beresiko tinggi tertusuk jarum.

Menurut Sahara (2011) tidak menutup kembali jarum suntik bekas pakai atau nonrecapping jarum adalah pilihan utama untuk mengurangi hazard terhadap perlukaan akibat tertusuk jarum suntik. Hal ini sejalan dengan pedoman kewaspadaan universal yang menjelaskan bahwa sangat tidak dianjurkan untuk menutup kembali jarum suntik tersebut, melainkan langsung saja dibuang ke tempat penampungan sementara tanpa menyentuh atau memanipulasi bagian tajamnya seperti dibengkokkan, dipatahkan atau ditutupl kembali. Jika jarum terpaksa ditutup kembali (recapping) maka perlu menggunakan cara penutupan jarum dengan satu tangan (onehanded scoop) untuk mencegah jari tertusuk jarum (Depkes, 2003).

Berdasarkan hasil penelitian didapatkan data bahwa perawat yang patuh dalam penerapan SOP teknik menyuntik sebanyak 46 perawat pelaksana $(95,8 \%)$, memiliki tindakan aman dalam pencegahan kejadian tertusuk jarum $79,2 \%$ atau sebanyak 38 responden dan sebesar $16,6 \%$ atau 8 responden memiliki tindakan tidak aman dalam pencegahan kejadian tertusuk jarum suntik di ruang rawat inap RSUD Kanjuruhan. Responden yang kurang patuh dalam penerapan SOP teknik menyuntik sebanyak 2 responden $(4,2 \%)$ memiliki tindakan tidak aman sebanyak $100 \%$ atau 2 responden memiliki risiko tinggi pencegahan kejadian tertusuk jarum. Dalam penelitian ini hasil uji Spearman di dapatkan tingkat signifikansi $(0,004)$ lebih kecil dari alpha $(0,05)$ dengan koefisien korelasi sebesar 0,406 yang bermakna memiliki hubungan yang signifikan dengan kekuatan hubungan sedang atau moderate antara kepatuhan perawat dalam penerapan teknik menyuntik dengan pencegahan kejadian tertusuk jarum di rumah sakit yang bertempat di RSUD Kanjuruhan. 


\section{KESIMPULAN DAN SARAN}

Berdasarkan hasil penelitian dan pembahasan, maka dapat diajukan beberapa saran yang dapat menjadi bahan pertimbangan dan masukan diharapkan pihak RSUD Kanjuruhan dapat melaksanakan pengawasan secara rutin pada saat perawat melakukan tindakan menyuntik di ruangan dan memberikan pelatihan tentang penanganan

\section{DAFTAR PUSTAKA}

American Nurses Association (ANA). 2002. Needlestick prevention guide. Proquest Dissertations and Theses. (Online), (http://www.who.int/occupational health/ activities/5prevent.pdf

Departemen Kesehatan. 2003. Pedoman Pelaksanaan Kewaspadaan Universal. Jakarta: Depkes RI.

Idayanti. 2008. Hubungan Pengetahuan Dan Sikap Perawat Terhadap Penerapan Standar Operasional Prosedur (SOP) Teknik Menyuntik Dalam Upaya Pencegahan Infeksi Di RSUD Arifin Achmad Pekanbaru. Tesis : Universitas Sumatera Utara, Medan.

Notoatmodjo, S. 2007. Promosi Kesehatan IImu dan Seni. Jakarta: PT Rineka Cipta

OHSAS 18001: 2007. Occuptional Health and Safety Management System Requerements jarum suntik di ruangan dan terkait SNSI secara berkala dan memprioritaskan pelatihan bagi perawat yang belum pernah mengikuti. Selain itu bagi peneliti selanjutnya dapat menggunakan perawat sebagai observer langsung pada saat responden melakukan tindakan menyuntik di ruangan agar peneliti memperoleh hasil penelitian yang lebih akurat.

Ramsay, D.J. 2005. A New Look at Nursing Safety: The Development and Use of JHAS in the Emergency Departement. The journal of SH \& E Research, Vol. 2, Num. 2.

Sholihah, Q, Djohan AJ. 2013. K3 RSMeminimalisasi kecelakaan dan penyakit akibat kerja di Rumah Sakit. Malang. Universitas Brawijaya Press.

Sahara, A. 2012. Faktor-faktor yang berhubungan dengan kepatuhan perawat dan bidan dalam penerapan kewaspadaan universal atau kewaspadaan standar di RS PMI Bogor. Skripsi. Fakultas Kesehatan Masyarakat Universitas Indonesia, Jakarta. 